Житомирська міська гімназія № 3

\title{
ФОРМУВАННЯ БЕЗПЕЧНОЇ ПОВЕДІНКИ МОЛОДШОГО ШКОЛЯРА ЯК НАУКОВА ПРОБЛЕМА
}

У статті проаналізовано проблему безпечної поведінки в психологопедагогічній та методичній літературі, розглядається етапи формування безпечної поведінки молодшого школяра.

Ключові слова: безпека, компетенція безпечної поведінки, молодший школяр.

Врятуйся сам - $і$ навколо тебе врятуються тисячі.

\section{Проблема, iï зв'язок із важливими науковими чи} практичними завданнями. 3 давніх-давен на людину чатували небезпеки, без цього життя не можливе. Безпека життєдіяльності найголовніше завдання, бо найвищою цінністю суспільства є людина іiі життя та здоров'я. Сьогодні сучасна людина живе у складному світі. Світ, який постійно змінюється та потребує від людини великих знань, умінь та досвіду. Щохвилини в країні, місті, районі трапляються неприємні, часто трагічні події, які забирають здоров'я та життя людей.

Оскільки від складної небезпечної ситуації ніхто не застрахований, тому кожному необхідно знати, як діяти в незвичайних ситуаціях. Умови сучасного життя вимагають якісного підвищення рівня освіти в нашій державі, у тому числі знань про небезпеки, що виникають як у побутовій, так і виробничій сфері.

Головне завдання сучасної школи - навчити дітей жити в динамічному, швидко мінливому сучасному світі, сформувати в учнів свідоме та відповідальне ставлення до особистої безпеки і безпеки інших людей.

Чимала кількість нещасних випадків, які трапляються 3 дітьми через необачне та безпечне поводження на дорогах, на воді, 3 пожежонебезпечними, вибуховими та іншими речовинами вимагають від педагогічних працівників більш сумлінної та відповідальної роботи.

Головне - вміти запобігти цим небезпекам чи зменшувати їх наслідки, захищати себе та оточуючих. Тому ефективне навчання 3 безпеки життя та діяльності людини $є$ лише не актуальним, а й першочерговим завданням освіти, мета якої - формування у людини 
правильної соціальної позиції щодо особистої безпеки та безпеки оточуючих, адекватного мислення й мотивації раціональної поведінки, фундаментальних знань, умінь, навичок щодо запобігання виникнення ризиків здоров'ю та життю від різноманітних небезпек.

Складні і суперечливі умови життєдіяльності сучасної дитини в умовах постійно змінюваного соціального довкілля потребують суттєвого переосмислення педагогічних підходів до побудови навчально-виховного процесу, що спрямовується на формування основ безпеки життєдіяльності дитини у довкіллі.

Аналіз публікацій (виділення невирішених проблем). На цій проблемі зосереджують увагу багато провідних учених 3 безпеки життєдіяльності, зокрема О. І. Запорожець, В. М. Ярошевська, В. І. Березуцький та інші.

Відповідна проблема знайшла відображення в педагогічних працях видатних учених світового значення (О. Декролі, Дж. Дьюї, Г. Кершенштейнер, Г. Лай, Е. Менман та інших) та вітчизняних педагогів (К. Н. Вентцель, М. О. Корф, П. Ф. Лесгафт, М. І. Пирогов та інших).

3 цими життєвими тенденціями сучасний науковець О. Кононко нерозривно пов'язує три важливих життєвих вміння, виховання яких $€$ пріорітетними завданнями у сучасному навчальному закладі: 1) орієнтація в довкіллі та у власному «Я»: Вміння виділяти головне і другорядне, безпечне i небезпечне, комфортне i дискомфортне; визначати доцільний напрям поведінки, прогнозувати ймовірні піi наслідки, розбиратися в основних характеристиках соціального оточення; 2) пристосування до нових умов життя: вміння застосовувати знайомий досвід в нових умовах життя, знаходити в новому позитивне, використовувати наявні в особистому досвіді знання і навички, виявляти гнучкість у спілкуванні з людьми; 3) вміння конструктивно впливати на довкілля та на самого себе: почуватися активним суб'єктом життєдіяльності, не задовольнятися пасивною роллю споживача активності інших, об'єкту впливів однолітків і дорослих, не втрачати власного особистісного начала, поступатися своїми інтересами в разі об'єктивної необхідності, оволодівати здатністю конструктивного розв'язування проблеми виходу з конфліктної ситуації, виробляти адекватні оцінки і реакції в різних життєвих ситуаціях.

Ціль статті - розкриття особливостей та умов формування у молодших школярів компетенцій безпечної поведінки.

Виклад основного матеріалу, обгрунтування результатів дослідження. Питання безпеки життя та здоров'я людини розглядається пріорітетним в контексті забезпечення сталого розвитку держави та суспільства. Учнів слід навчати користуватися моделями 


\section{Збірник наукових статей}

безпеки, а саме: визначати небезпеку, що наближається чи виникла, аналізувати рівень небезпеки приймати правильне рішення стосовно неї, усвідомлено діяти. У сфері освіти на кожному етапі навчальновиховного процесу в учнів необхідно формувати знання і поняття про найбільш поширені небезпечні ситуації у житті та уміння і навички їх подолання.

Безпека - одна 3 найбільших цінностей людини й суспільства. Аналізуючи зміст терміну «безпека», дослідники доходять висновку, що в суспільній свідомості це поняття ототожнюється не скільки 3 відсутністю загроз, скільки зі станом, почуттями та переживаннями людей.

Для вирішення цього завдання необхідно підготувати учнів до дій у надзвичайних ситуаціях, раціональних, ефективних, психологічно i морально обгрунтованих дій, тобто сформувати готовність до творчої діяльності в будь-якій екстремальній ситуації.

Необхідно вчити дітей ефективно використовувати адаптаційні можливості організму в ускладнених умовах існування (викликані природними факторами, аваріями, катастрофами тощо), переносити підвищені фізичні та психологічні навантаження, переборювати втому, стресові стани. Опановуючи елементи культури особистої безпеки під час ознайомлення 3 різними джерелами небезпеки, засвоюючи нові способи та засоби виживання, навчаючись того, як уникнути неприємних ситуацій чи перебороти їх і з мінімальними витратами, школярі вчаться застосовувати набуті знання у повсякденному житті.

Оскільки процес накопичення особистого досвіду здійснюється досить повільно та безсистемно, під час ознайомлення з відомостями стосовно особистої безпеки необхідно не тільки інформувати учнів про потенційну небезпеку, але й учити їх аналізувати причини нещасних випадків, складати оптимальні моделі безпечної поведінки конкретних ситуаціях. Набуті навички можуть стати основою для безпеки, що базується на конкретних знаннях, на почутті міри та розумінні загальної логіки безпеки: «передбачати небезпеку, по можливості уникати іiі, за потреби - діяти». Саме 3 цією метою необхідно використовувати ситуаційне навчання, метод аналізу конкретних ситуацій, моделювання безпечної поведінки.

Необхідна організація практичної, ігрової, індивідуальної та колективної діяльності учнів, що грунтується на суб'єкт-суб'єктній взаємодії вчителя з учнями. Такий підхід отримав назву «освіта на основі набуття життєвих навичок» і характеризується застосуванням інтеративних методів навчання, що забезпечує ефективне засвоєння учнями навчального матеріалу і відрацювання ними поведінкових навичок. 
Відповідні знання, уміння й навички є необхідною умовою безпечної поведінки людини, цим питанням приділяється значна увага в освітній сфері.

Безпечна поведінка визначається як система дій або вчинків особистості, спрямованих на забезпечення оптимального рівня захищеності в усіх сферах життєдіяльності, що характеризує загальне ставлення людини як до власної безпеки, життя і здоров'я так до оточуючих, екологічно безпечного природного середовища.

Учень набуває навичок у діяльності, через прийняття рішень та відпрацювання моделей поведінки. Тому на відміну від традиційних уроків, коли вчитель переважно говорить, а учні слухають, слід використовувати на заняттях інтерактивні методи.

На уроках цікавим та повчальним $\epsilon$ розігрування певних життєвих ситуацій після усного обговорення теми. Це допомагає дітям не лише усвідомити нову інформацію, але й навчитися застосовувати іiі на практиці під керівництвом вчителя. Існує безліч відео повчального характеру, що демонструють небезпечні ситуації та шляхи їх вирішення.

Важливою ланкою в формування безпечної поведінки школярів $€$ робота вчителя з батьками, оскільки більшість часу діти проводять саме 3 ними.

Формування в учнів безпечної поведінки має проходити на уроці за такими етапами:

1. Підготовчий етап. Полягає в отриманні вражень про небезпеку, що може чатувати на дітей у довкіллі. Це може бути у вигляді спостереження, перегляду відеофільмів, мультфільмів, прогулянка або екскурсія.

2. Основний етап. Робота з формування певної системи уявлень та вироблення навичок безпечної поведінки. На цьому етапі доцільно застосувати різні види ігор з елементами безпечної поведінки, бесіди, складання описових та творчих розповідей дітьми.

3. Практичний етап. На цьому етапі діти мають застосовувати набуті знання та вміння на практиці. Доречним буде розв'язання проблемних ситуацій, творчих завдань, розваг, змагань, конкурсів.

Висновки, перспективи. Таким чином, підгрунтям для формування безпечної поведінки є система взаємопов'язаних наукових i емпіричних знань, умінь і навичок, що необхідні для формування мотиваційно-вольового, змістовного, операційного компонентів готовності учнів початкової ланки до культури безпечної поведінки. Вжиття заходів, а саме: безпечної поведінки на дорозі, в лісовій місцевості, на узбіччях, на воді, у громадському транспорті, у навчальних закладах, із незнайомими людьми, 3 небезпечними предметами та інше, спрямовані на формування правильної соціальної 


\section{Збірник наукових статей}

позиції особи щодо власної безпеки. Саме ці знання молодший школяр отримує на уроках під час навчально- виховного процесу під керівництвом вчителя.

\section{Література}

1. Богданова Г. Підготовка вчителів до формування в учнів життєвих навичок / Г. Богданова // Здоров'я та фізична культура. 2007. - № 9. - С. 6-7.

2. Запорожцев А. В. Твоя безпека / А. В. Запорожцев, В. О. Брижик, Т. Є. Руденко. - К. : ОБСЄ, 2009. - 51 с.

3. Зоріна М. О. До проблеми визначення актуальності й особливостей формування культури безпеки життєдіяльності / М. О. Зоріна // Педагогіка формування творчої особистості у вищій і загальноосвітній школах. - 2010. - № 8. - С. 149-153.

4. Про створення Національної ради 3 питань безпечної життєдіяльності населення : Постанова Кабінету Міністрів України від 15.09.1993 р. № 733 [Електронний ресурс]. - Режим доступу : http://zakon3.гada.goy.ua/laws/show/733-93- \%D0\%BF. - Назва 3 титул. екрану.

5. Волкова І. В. Система роботи з безпеки життєдіяльності в загальноосвітньому навчальному закладі: збірник нормативних i методичних матеріалів / I. В. Волкова, Н. О. Холодова. - Х. : ХОНМІБО, 2005. $-44 \mathrm{c}$.

6. Холодова Н. О. Скажи собі відверто : методичний посібник щодо упровадження ситуаційного навчання на уроках та в позаурочний час / Н. О. Холодова, Т. С. Прокопенко. - Х. : Харківська академія неперервної освіти, 2011. - 76 с.

7. Холодова Н. О. Допоможи собі сам/ Н. О. Холодова., Т. С. Прокопенко. - Х. : ХОНМІБО, 2003. - 48 с.

Юлия Давыденко. Формирование безопасного поведения младшего школьника как научная проблема.

В статье проанализирована проблема безопасного поведения в психолого-педагогической и методической литературе, рассматривается этапь формирования безопасного поведения младших школьников.

Ключевые слова: безопасность, компетенщия безопасного поведения, младиий школьник.

\section{problem.}

Julia Davydenko. Safe behavior younger student as a scientific

In the article the problem of safe behavior in psychological, pedagogical and methodological literature considered stages of primary school children safe behavior.

Keywords: safety, competence safe behavior of younger schoolchildren.

Стаття надійшла до редакційної колегії 08.05.2017 